\title{
Originals
}

\section{Temporal Relationship of Glycosylated Haemoglobin Concentrations to Glucose Control in Diabetics}

\author{
P. J. Dunn, R. A. Cole, J. S. Soeldner, R. E. Gleason, E. Kwa, H. Firoozabadi, D. Younger, and C. A. Graham \\ E. P. Joslin Research Laboratory and Joslin Clinic Division of the Joslin Diabetes Foundation, Inc., Boston, MA, New England Deaconess \\ Hospital, and Department of Medicine, Peter Bent Brigham Hospital and Harvard Medical School, Boston, MA, USA
}

Summary. To examine the temporal relationship between $\mathrm{Hb} \mathrm{A}_{\mathrm{Ic}}$ values and various indices of blood glucose control, 38 diabetic and 28 nondiabetic youth counsellors employed at two summer camps for diabetic children took part in an eight-week study. Each week fasting determinations were made of $\mathrm{Hb}$ $A_{I}, \mathrm{Hb} A_{1 c}$, serum cholesterol, triglyceride and growth hormone and plasma glucose. Total daily urine glucose excretion was measured approximately two times per week, capillary glucose values were measured fasting and at $11 \mathrm{a} . \mathrm{m}$. and $3 \mathrm{p}$. m. on two days per week, and urine glucose was measured semiquantitatively four times per day. As $\mathrm{Hb} \mathrm{A}_{\mathrm{I}}$ was correlated highly with $\mathrm{Hb} \mathrm{A}_{\mathrm{Ic}}$ ( $\left.\mathrm{r}=0.997\right)$, it was used as the primary index of glycosylated haemoglobin. The mean values of $\mathrm{Hb} \mathrm{A_{I }}$, serum cholesterol and triglycerides and fasting plasma glucose were all significantly elevated in the diabetic group but only $\mathrm{Hb} \mathrm{A}_{\mathrm{I}}$ values provided total separation of the two groups. Within the diabetic group the Week $8 \mathrm{Hb} \mathrm{A}$ values showed a significant correlation with the Week 8 mean capillary glucose concentrations, the proportion of urine tests showing $2 \%$ and $0 \%$ glycosuria, and mean serum triglycerides. Correlations of Week $8 \mathrm{Hb} \mathrm{A}$ with the mean values of these glycaemic parameters for each week of the study demonstrated low order correlations with the glycaemic measures of Week 1, and a progressive increase in the degree of correlation reaching a plateau with the glycaemic measures of Week 4 to 8 . Similar correlation analysis using the $\mathrm{Hb} \mathrm{A}_{I}$ values from Week 4 confirmed these findings. Therefore, while $\mathrm{Hb} \mathrm{A}_{\mathrm{I}}$ provides an index of the control of diabetes, it appears to be more acutely responsive to blood glucose alteration than generally recognized.

Key words: Glycosylated haemoglobin, juvenile diabetics, mean capillary blood glucose, fasting plasma glucose, twenty-four hour urine glucose, cholesterol, triglycerides, camps, weekly.
Following the initial observation that the minor haemoglobin, haemoglobin $(\mathrm{Hb}) \mathrm{A}_{\mathrm{Ic}}$, is increased in diabetic subjects $[1,2]$ it has been established that $\mathrm{Hb} \mathrm{A} \mathrm{A}_{\mathrm{Ic}}$ is a glycosylated derivative of the major adult haemoglobin, $\mathrm{Hb} \mathrm{A}_{\mathrm{II}}[3,4,5,6]$. Hexose molecules attach to the $\mathrm{N}$-terminals of the two $\mathrm{B}$ chains of the $\mathrm{Hb} \mathrm{A}_{\mathrm{II}}$ molecule, initially in a reversible Schiff base linkage but subsequently they rearrange spontaneously to form a more stable ketoamine linkage [3]. Two further minor haemoglobin components $\mathrm{Hb} \mathrm{A}_{\text {Ia }}$ and $\mathrm{Hb} \mathrm{A}_{\mathrm{Ib}}$ are commonly measured as a single entity, $\mathrm{Hb} \mathrm{A}_{\mathrm{Ia}+\mathrm{b}}$, which is also increased in the diabetic $[7,8]$. All three minor haemoglobin components are formed postsynthetically, their concentrations increasing slowly and apparently linearly over the life-span of a cohort of red cells [6].

On the basis of these observations, and the known constancy of red blood cell survival [9] it has been proposed that the concentration of $\mathrm{Hb} \mathrm{A}_{\mathrm{Ic}}$ should provide a measure of the average blood glucose concentrations prevailing over the life-span of the red cells sampled [6, 10]. Gabbay et al. [7] observed that $\mathrm{Hb} \mathrm{A}_{\mathrm{I}}$ correlated significantly with 24$h$ urine glucose excretion determined at monthly intervals over a three-month period prior to the $\mathrm{Hb}$ $\mathrm{A}_{\mathrm{I}}$ sample in a large group of juvenile diabetics. The highest correlation was between the $\mathrm{Hb} \mathrm{A}_{I}$ level and the 24-hour urine glucose obtained two months prior to $\mathrm{Hb} \mathrm{A}_{\mathrm{I}}$ determination. In addition, Ditzel et al. [11] noted that $\mathrm{Hb} \mathrm{A}_{\mathrm{Ic}}$ values fell over a period of weeks to months following initiation of insulin therapy in a group of newly diagnosed diabetics. On the other hand, the rate of decline of $\mathrm{Hb} \mathrm{A}_{\mathrm{Ic}}$ values following imposition of rigorous diabetic control in a group of five diabetics described by Koenig et al. [12] appeared inconsistent with a reduction in rate of synthesis alone. Furthermore, high correlations have been reported between $\mathrm{Hb} \mathrm{A}_{\mathrm{Ic}}$ values and virtually simultaneous blood glucose concentrations $[13,14]$. Finally, short-term changes in blood glucose concen- 
trations have been reported to influence $\mathrm{Hb} \mathrm{A}_{\mathrm{Ic}}$ values [15].

In view of the clinical importance of the relationship between blood glucose concentrations and the related $\mathrm{Hb} \mathrm{A}_{\mathrm{Ic}}$ concentrations, and in particular, the response of the latter to blood glucose changes, we have examined this relationship in a group of thirtyeight juvenile onset diabetics studied for an eightweek period.

\section{Methodology}

\section{Subjects}

Thirty-eight diabetic and 28 nondiabetic counsellors at the E. P. Joslin and Clara Barton Diabetic Camps volunteered for the study. The diabetic group comprised 20 male subjects, mean age $19.1 \pm 0.5$ years $( \pm \mathrm{SEM})$, mean $\%$ of Ideal Body Weight ( $\%$ IBW) $108 \pm 2$, and 18 female subjects, mean age $19.4 \pm 1.1$ years and mean \% IBW $111 \pm 4$. All were on insulin therapy and had no major diabetic complications. The nondiabetic group comprised 6 male subjects, mean age $20.8 \pm 1.3$ years, mean \% IBW $106 \pm 5$, and 22 female subjects, mean age $20.9 \pm 0.6$ years and mean $\%$ IBW 104 \pm 3 . Informed written consent was obtained from all subjects prior to the study and countersigned by a parent or guardian in the case of minors.

\section{Procedures}

The study was performed during the course of a summer camp session of eight-weeks duration. Each Monday following an overnight fast, a blood sample was drawn for determination of plasma glucose, serum triglycerides, serum growth hormone, and glycosylated haemoglobin in both the diabetic and nondiabetic subjects. The diabetic subjects tested their urine semiquantitatively four times a day for glucose concentration, provided two or more 24-h urine collections per week for glucose determination and on two or more days per week had capillary glucose concentrations determined fasting, at $11 \mathrm{a} . \mathrm{m}$. and at $3 \mathrm{p} . \mathrm{m}$.

\section{Methods}

$\mathrm{Hb} \mathrm{A}_{\mathrm{Ic}} \%$ and $\mathrm{Hb} \mathrm{A}_{\mathrm{I}} \%$ were determined with a high performance liquid chromatography technique [16]. Aliquots of a pooled haemolysate were kept in liquid nitrogen and run at the beginning and end of each day's samples. The inter- and intra-run coefficients of variation of the quality control sample were both approximately $3 \%[16]$. Serum cholesterol and serum triglycerides were measured with an automated colorimetric method [17], and serum growth hormone by radioimmunoassay [18]. The fasting plasma glucose levels were determined with a glucose oxidase method [19], the capillary glucose levels with Dextrostix and the Eyetone Reflectance Meter (Ames Company, Elkhart, Indiana). Twentyfour $h$ urine glucose excretion was measured with Sumner's technique [20]. To assess the adequacy of the 24-h urine collections, the total creatinine excretion was determined from two collections for each subject. The mean total creatinine excretion ( \pm SEM) was $1.20 \pm 0.05 \mathrm{~g} /$ day. The daily semiquantitative urine glucose tests were determined with Benedict's solution, the results being expressed in $\mathrm{g} / 100 \mathrm{ml}$ ranging from $0 \%$ to $2 \%$. For purposes of analysis the total number of $0 \%$ and $2 \%$ urine tests recorded by each subject for each week of the study were calculated as the proportion of the total number of tests for the week.

\section{Statistical Analyses}

The data for all the subjects were processed by an IBM Model $370 / 168$ computer using the Data Text program package [21]. The statistical analyses involved the computation of conventional correlation coefficients and regression equations; differences between two group means were determined by Student's t-test, either paired or unpaired where appropriate. All data are expressed as mean $\pm \mathrm{SEM}$.

\section{Results}

Relationship of $\mathrm{Hb} \mathrm{A}_{I} \%$ to $\mathrm{Hb} A_{I c} \%$

The relationship of $\mathrm{Hb} \mathrm{A}_{\mathrm{I}} \%$ with $\mathrm{Hb} \mathrm{A}_{\mathrm{Ic}} \%$ values recorded in the diabetic and nondiabetic subjects in Week 1 of the study was calculated. The correlation coefficient was close to $1(r=0.996, p<0.001)$, and the regression equation was: $9 \mathrm{Hb} \mathrm{A}_{\mathrm{I}}=1.02+1.14$ $\mathrm{Hb} \mathrm{A}_{\mathrm{Ic}}$. Repeated analysis of this relationship for Weeks $2-8$ of the study produced correlation coefficients of a similarly high magnitude, and the regression equations were virtually identical.

\section{Diabetic Compared to Nondiabetic Values}

The diabetic and nondiabetic fasting plasma glucose, serum cholesterol, serum triglyceride and $\mathrm{Hb} \mathrm{A}_{\mathrm{I}}$ values recorded in Week 1 of the study are depicted in Figure 1 . The mean values of all four variables were significantly greater in the diabetic group $(\mathrm{p}<0.001$, with cholesterol, $\mathrm{p}<0.05$ ). There was no overlap of the diabetic and nondiabetic $\mathrm{Hb} \mathrm{A}_{\mathrm{I}} \%$ values (with one exception), but marked overlap of the other three variables.

Mean levels of $\mathrm{Hb} \mathrm{A}_{\mathrm{I}}$, fasting plasma glucose, serum cholesterol and serum triglyceride concentrations for both diabetics and nondiabetics in each week of the study are listed in Table 1 . The significant differences noted between the two groups in the first week were maintained over the eight weeks although not consistently for cholesterol.

The mean serum growth hormone concentrations did not differ significantly between the two groups for any of the eight weeks (data not shown). The mean values in the diabetics over the eight weeks ranged from 3.6 to $2.0 \mathrm{ng} / \mathrm{ml}$; in the nondiabetics the range was from 3.6 to $2.1 \mathrm{ng} / \mathrm{ml}$.

To assess the relative stability of $\mathrm{Hb} \mathrm{A}_{\mathrm{I}}$ in the diabetic compared to the nondiabetic subjects, the mean, standard deviation and coefficient of variation of $\mathrm{Hb} \mathrm{A}_{\mathfrak{I}}$ were calculated for each diabetic and nondiabetic subject from the eight values determined over the study period. The mean coefficient of variation in the diabetic and nondiabetic groups respectively were $9.1 \pm 0.7 \%$ vs $6.6 \pm 0.5 \%(\mathrm{p}<0.01)$. 


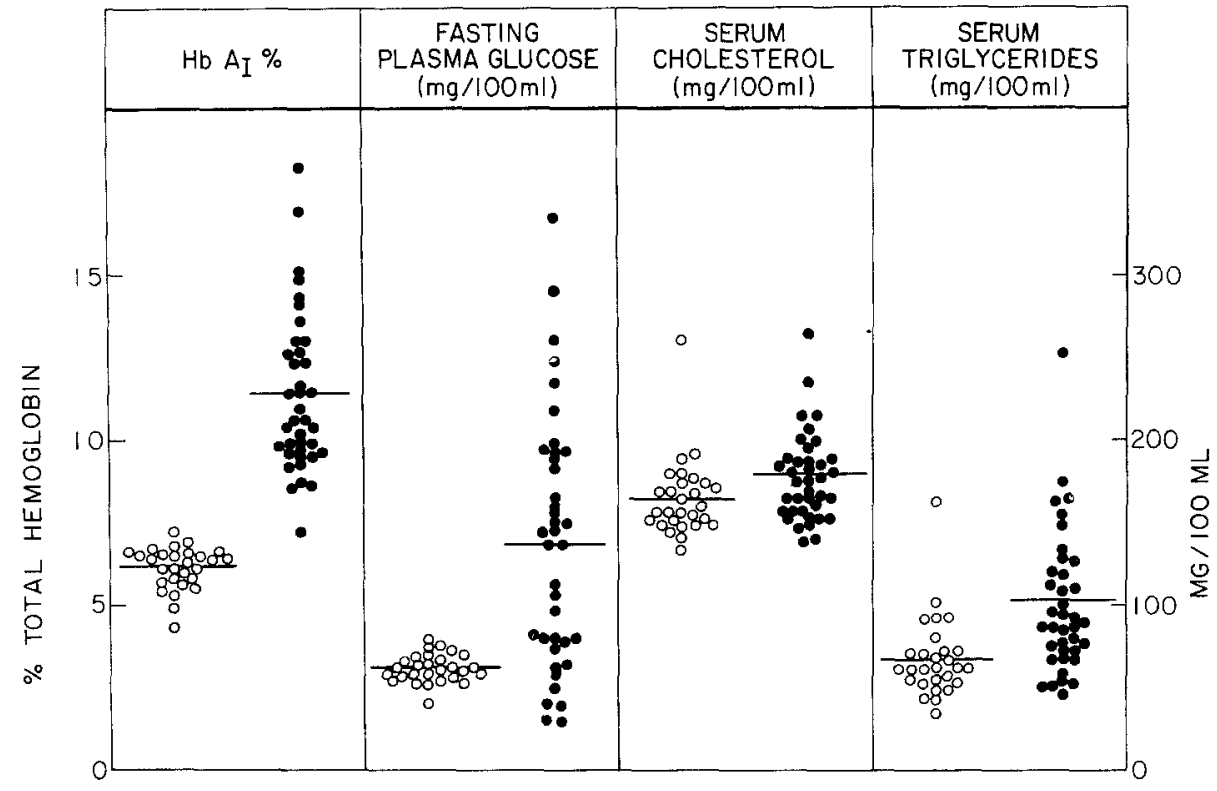

Fig. 1. Week $1 \mathrm{Hb} \mathrm{A}_{\mathrm{I}}$, fasting plasma glucose, fasting serum cholesterol and fasting serum triglyceride concentrations in 38 diabetic and 28 nondiabetic subjects. $0=$ Nondiabetics, $\bullet=$ Diabetics

Table 1. Mean ( \pm SEM) of weekly fasting metabolic values in 28 non-diabetic and 38 diabetic subjects

\begin{tabular}{|c|c|c|c|c|c|c|c|c|c|}
\hline Weeks & 1 & 2 & 3 & 4 & 5 & 6 & 7 & 8 & \\
\hline $\mathrm{Hb} \mathrm{A}_{\mathrm{I}}(\%)$ & $\begin{aligned} 6.2 \pm 0.1 \\
11.4 \pm 0.4 \\
p<0.001\end{aligned}$ & $\begin{array}{r}6.1 \pm 0.2 \\
11.1 \pm 0.4 \\
<0.001\end{array}$ & $\begin{array}{r}6.1 \pm 0.1 \\
10.9 \pm 0.4 \\
<0.001\end{array}$ & $\begin{array}{r}6.2 \pm 0.1 \\
10.7 \pm 0.4 \\
<0.001\end{array}$ & $\begin{array}{r}6.3 \pm 0.1 \\
10.9 \pm 0.4 \\
<0.001\end{array}$ & $\begin{array}{r}6.5 \pm 0.2 \\
11.3 \pm 0.4 \\
<0.001\end{array}$ & $\begin{array}{r}6.2 \pm 0.1 \\
11.1 \pm 0.3 \\
<0.001\end{array}$ & $\begin{array}{r}6.3 \pm 0.1 \\
10.7 \pm 0.4 \\
<0.001\end{array}$ & $\begin{array}{l}\text { Non-diabetic } \\
\text { Diabetic }\end{array}$ \\
\hline $\begin{array}{l}\text { Fasting plasma } \\
\text { glucose } \\
(\mathrm{mg} / 100 \mathrm{ml})\end{array}$ & $\begin{array}{c}62 \pm 2 \\
137 \pm 13 \\
p<0.001\end{array}$ & $\begin{array}{l}57 \pm 1 \\
168 \pm 16 \\
<0.001\end{array}$ & $\begin{array}{r}66 \pm 2 \\
187 \pm 14 \\
<0.001\end{array}$ & $\begin{array}{l}63 \pm 2 \\
166 \pm 13 \\
<0.001\end{array}$ & $\begin{array}{l}75 \pm 3 \\
180 \pm 16 \\
<0.001\end{array}$ & $\begin{array}{c}82 \pm 2 \\
212 \pm 19 \\
<0.001\end{array}$ & $\begin{array}{l}80 \pm 2 \\
154 \pm 16 \\
<0.001\end{array}$ & $\begin{array}{c}63 \pm 1 \\
155 \pm 2 \\
<0.001\end{array}$ & $\begin{array}{l}\text { Non-diabetic } \\
\text { Diabetic }\end{array}$ \\
\hline $\begin{array}{l}\text { Serum } \\
\text { cholesterol } \\
(\mathrm{mg} / 100 \mathrm{ml})\end{array}$ & $\begin{array}{l}164 \pm 5 \\
178 \pm 4 \\
p<0.05\end{array}$ & $\begin{array}{l}147 \pm 5 \\
159 \pm 5 \\
N S\end{array}$ & $\begin{array}{l}158 \pm 6 \\
179.5 \pm 5.6 \\
<0.02\end{array}$ & $\begin{array}{l}159 \pm 6 \\
168.9 \pm 4.3 \\
\text { NS }\end{array}$ & $\begin{array}{l}159 \pm 6 \\
170.0 \pm 4.9 \\
\text { NS }\end{array}$ & $\begin{array}{l}167 \pm 6 \\
182.2 \pm 6.1 \\
\text { NS }\end{array}$ & $\begin{array}{l}166 \pm 7 \\
184.4 \pm 5.5 \\
<0.05\end{array}$ & $\begin{array}{l}164 \pm 6 \\
171.9 \pm 4.6 \\
\text { NS }\end{array}$ & $\begin{array}{l}\text { Non-diabetic } \\
\text { Diabetic }\end{array}$ \\
\hline $\begin{array}{l}\text { Triglycerides } \\
(\mathrm{mg} / 100 \mathrm{ml})\end{array}$ & $\begin{array}{c}68 \pm 5 \\
102 \pm 7 \\
p<0.001\end{array}$ & $\begin{array}{c}63 \pm 2 \\
84 \pm 6 \\
<0.001\end{array}$ & $\begin{array}{l}79 \pm 6 \\
133 \pm 23 \\
<0.05\end{array}$ & $\begin{array}{r}73 \pm 3 \\
94 \pm 6 \\
<0.001\end{array}$ & $\begin{array}{c}75 \pm 1 \\
106 \pm 7 \\
<0.001\end{array}$ & $\begin{array}{l}74 \pm 5 \\
95 \pm 10 \\
\text { NS }\end{array}$ & $\begin{array}{c}71 \pm 4 \\
89 \pm 6 \\
<0.02\end{array}$ & $\begin{array}{l}72 \pm 7 \\
103 \pm 12 \\
<0.05\end{array}$ & $\begin{array}{l}\text { Non-diabetic } \\
\text { Diabetic }\end{array}$ \\
\hline
\end{tabular}

\section{Weekly Mean Glycaemia in the Diabetic Group}

The weekly mean values in the diabetic group for capillary glucose, 24-hour urine glucose excretion, proportion of $2 \%$ and $0 \%$ urine tests are listed in Table 2. A statistically significant increase in mean capillary glucose values was observed in Weeks 5, 6 and 8 compared with Week 1 on paired t-test analysis, also in 24-h urinary glucose in Week 6 and a significant decrease in the proportion of $0 \%$ urine tests in Weeks 2, 3, 4, 5, 6 and 8.

\section{Correlation of Week $8 \mathrm{Hb} A_{I}$ Values with Mean Glycaemia in the Antecedent Eight Weeks of the Study}

The mean values for capillary glucose, proportion of $2 \%$ and $0 \%$ urine tests, $24-\mathrm{h}$ urine glucose excretion, serum cholesterol and serum triglyceride concentrations over the eight weeks of the study were calculated for each diabetic subject and correlated with the $\mathrm{Hb} \mathrm{A}_{\mathrm{I}}$ values from Week 8 (Figure 2). The highest correlation was noted with the mean capillary glu$\operatorname{cose}(r=0.78 ; p<0.001)$. Somewhat lower, but still 
Table 2. Mean ( \pm SEM) glycaemic index values for weeks one to eight

\begin{tabular}{llllllllllllllllll}
\hline Weeks & 1 & & 2 & & 3 & & 4 & & 5 & & 6 & & 7 & 8 \\
\hline $\begin{array}{l}\text { Mean capillary } \\
\text { glucose mg/100 ml }\end{array}$ & 140 & \pm 6 & 158 & \pm 10 & 148 & \pm 8 & 162 & \pm 10 & $184^{\mathrm{c}}$ & \pm 10 & $174^{\mathrm{a}}$ & \pm 11 & 159 & \pm 10 & $209^{\mathrm{c}}$ & \pm 18 \\
$\begin{array}{l}24 \text { hour urine } \\
\text { glucose g/day }\end{array}$ & 16 & \pm 3 & 14 & \pm 2 & 20 & \pm 3 & 22 & \pm 4 & 20 & \pm 3 & $33^{\mathrm{b}}$ & \pm 4 & 18 & \pm 2 & 23 & \pm 4 \\
$\begin{array}{l}\text { Proportion } 2 \% \\
\text { urine tests }\end{array}$ & $0.22 \pm 0.03$ & $0.26 \pm 0.03$ & $0.22 \pm 0.03$ & $0.28 \pm 0.04$ & $0.29 \pm 0.04$ & $0.24 \pm 0.04$ & $0.19 \pm 0.03$ & $0.22 \pm 0.22$ \\
$\begin{array}{l}\text { Proportion } \% \\
\text { urine tests }\end{array}$ & $0.40 \pm 0.04$ & $0.32^{\mathrm{a}} \pm 0.04$ & $0.33^{\mathrm{a}} \pm 0.04$ & $0.28^{\mathrm{b}} \pm 0.04$ & $0.21^{\mathrm{c}} \pm 0.03$ & $0.31^{\mathrm{a}} \pm 0.04$ & $0.36 \pm 0.04$ & $0.28^{\mathrm{a}} \pm 0.04$ \\
\hline
\end{tabular}

${ }^{\mathrm{a}} \mathrm{p}<0.05 ;{ }^{\mathrm{b}} \mathrm{p}<0.01 ;{ }^{\mathrm{c}} \mathrm{p}<0.001$

Paired t-test analysis of changes in glycaemic parameters between week 1 and the later weeks of the study
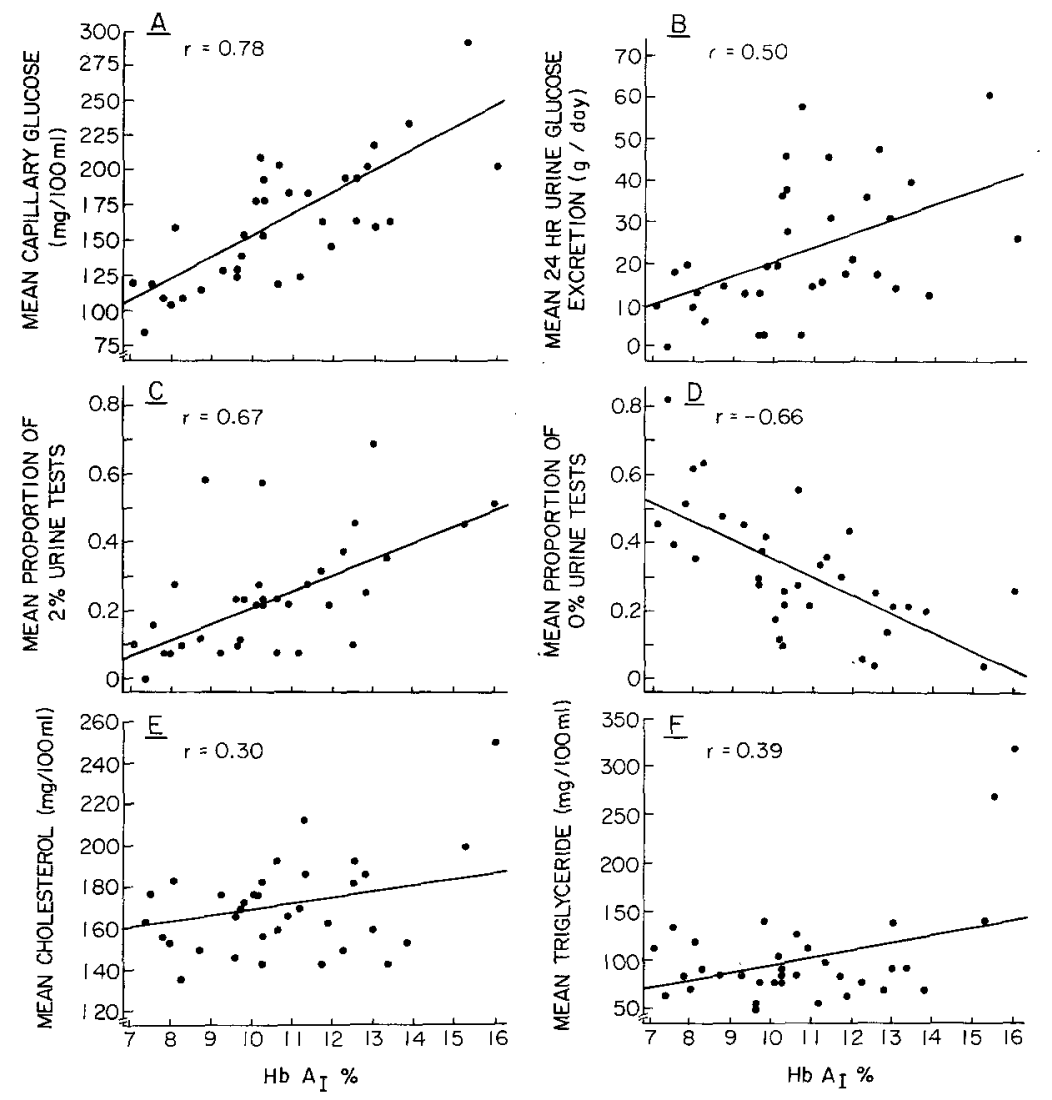

Fig. 2. Relationship in the diabetics of $\mathrm{Hb} \mathrm{A}_{\mathrm{I}} \%$ on Week 8 with the mean values of the capillary glucose determinations, 24-hour urinary glucose excretion, proportion of $2 \%$ and $0 \%$ urine tests, and fasting serum cholesterol and fasting serum triglyceride concentrations over the eight week study period. Significance of $\mathrm{r}$ and $\mathrm{n}$ for panel $\mathrm{A}$ is $p<0.001$ and 35 , panel $B$ is $p<0.001$ and 35 , panel $C$ is $p<0.001$ and 34 , panel $D$ is $p<0.001$ and 34 , panel $\mathrm{E}$ is $\mathrm{p}=\mathrm{ns}$ and 34 and panel $\mathrm{F}$ is $\mathrm{p}<0.025$ and 34

highly significant correlations were observed with the mean 24-h urine glucose excretion $(\mathrm{r}=0.50 ; \mathrm{p}<$ $0.001)$, the proportion of $2 \%$ tests $(r=0.67 ; p<$ $0.001)$, and the proportion of $0 \%$ tests $(r=-0.66 ; p$ $<0.001$ ). A significant correlation was noted with mean triglycerides $(r=0.39 ; \mathrm{p}<0.025)$ but not with mean cholesterol $(r=0.30 ; p<0.1)$.

\section{Correlation of $\mathrm{Hb} \mathrm{A}_{I}$ with Mean Weekly Glycaemia}

To examine the influence of degree of control in each week on the $\mathrm{Hb} \mathrm{A}_{\mathrm{I}}$ values determined at the end of the study, the weekly mean capillary glucose, fasting plasma glucose, 24-h urine glucose excretion and proportion of $2 \%$ and $0 \%$ urine test values were calculated for each diabetic subject. These weekly indices of glycaemia were then correlated with the Week $8 \mathrm{Hb} \mathrm{A}_{\mathrm{I}}$ values (Figure 3 - upper panel). Low magnitude statistically significant correlations were noted between $\mathrm{Hb} \mathrm{A}_{\mathrm{I}}$ values and most of the indices of glycaemia in Week 1 of the study but the degree of correlation improved progressively from Week 1 to a plateau from Week 4 to 8 . Similar correlation analysis of Week $4 \mathrm{Hb} \mathrm{A}_{I}$ values illustrated that $\mathrm{Hb} \mathrm{A}_{\mathrm{I}}$ correlated maximally with the degree of glycaemia in the immediately preceding Week 3 (Figure 3 - lower 
panel). In addition, it was apparent that the change of glucose control from week to week within the subjects was such that the predictive value of the Week 4 $\mathrm{Hb} \mathrm{A}_{\mathrm{I}}$ for subsequent glycaemia was restricted to approximately one week (Figure 3 - lower panel).

For control purposes, the mean 24-h urine glucose excretion in Week 8 of the study was correlated for each subject with their mean weekly indices of glycaemia, as shown in Figure 4. It was apparent that the Week 8 mean 24-h urine glucose excretion correlated highly significantly with four of the five indices of glycaemia in the last five weeks of the study. Thus, the stability of glucose control in the latter half of the study undoubtedly influenced the period of time for which the Week $8 \mathrm{Hb} \mathrm{A}_{I}$ was useful as an index of prior glucose control.

Correlation of $\mathrm{Hb} A_{I}$ with Antecedent Weekly Serum Fasting Lipids

The correlation coefficients of Week $8 \mathrm{Hb} \mathrm{A}_{\mathrm{I}}$ values with the weekly serum cholesterol and serum triglyceride concentrations of the diabetic subjects are listed in Table 3. The Week $8 \mathrm{Hb} \mathrm{A}_{\mathrm{I}}$ values correlated significantly with both these serum lipids for Weeks 3 and 4 and with triglycerides in Week 7 (Table 3).

\section{Discussion}

To date, the lack of a simple and rapid analytical method has greatly restricted the clinical evaluation of $\mathrm{Hb} \mathrm{A}_{\mathrm{I}}$ and $\mathrm{Hb} \mathrm{A}_{\mathrm{Ic}}$ measurements. In the present study, a high performance liquid chromatography method was used that permitted both variables to be determined with a considerable degree of accuracy in a large number of samples. The high degree of correlation noted by Gabbay et al. [7] between $\mathrm{Hb} \mathrm{A}_{\mathrm{I}}$ and $\mathrm{Hb} \mathrm{A}_{\mathrm{Ic}}$ was confirmed in this study, and in addition, it was demonstrated that this relationship (as evidenced by regression analysis) remained constant on repetitive determinations over an eight-week period. Therefore, for clinical purposes, it seems reasonable to use the simpler measurement of $\mathrm{Hb} \mathrm{A}_{I}$ alone in place of the more lengthy determination of $\mathrm{Hb} \mathrm{A} \mathrm{A}_{\mathrm{Ic}}$. The one proviso to this is the need for greater care in sample handling for there is a progressive increase in

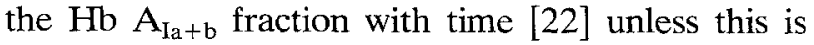
obviated by storage at $-80^{\circ} \mathrm{C}$ or prompt analysis of the samples. With present technology, however, $\mathrm{Hb}$ $A_{I}$ can be determined in approximately ten minutes per sample [16] and accordingly this method is feasible for routine clinical application.

The $\mathrm{Hb} \mathrm{A}_{\mathrm{I}}$ values noted in this study in the diabe-

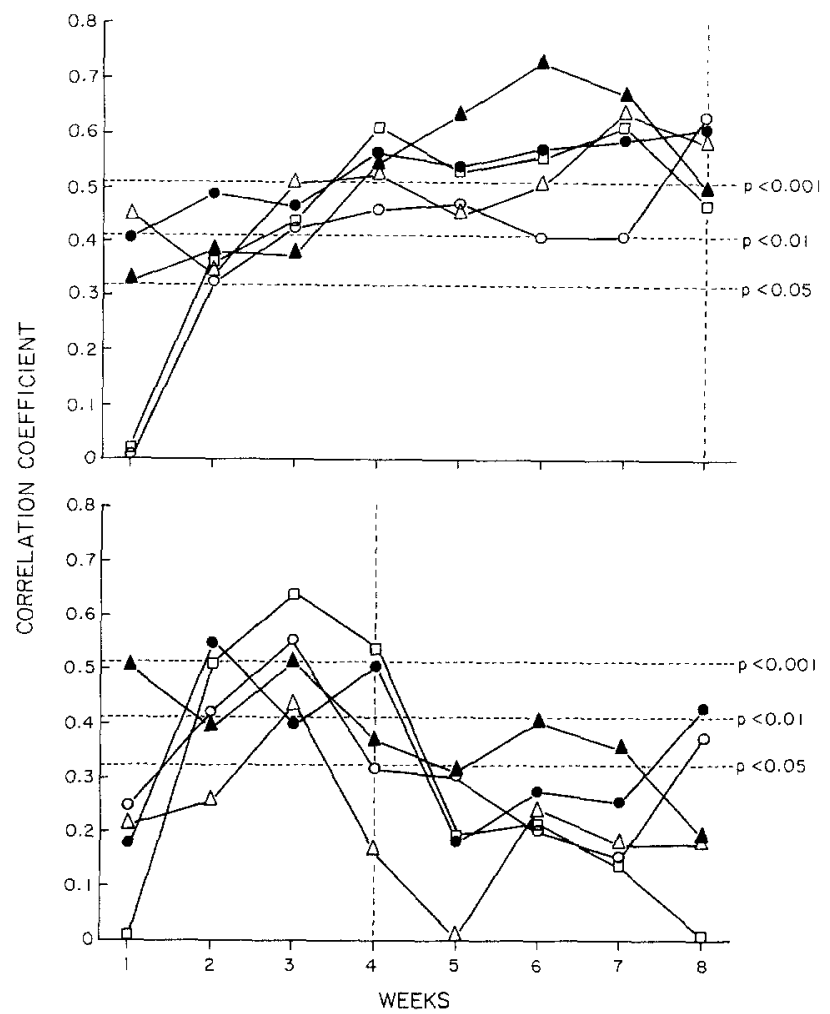

Fig. 3. Correlation coefficients between $\mathrm{Hb} \mathrm{A}_{\mathrm{I}} \%$ values from Weeks 8 (top panel) and 4 (bottom panel) and the mean weekly metabolic parameters for Weeks 1-8 for the 38 diabetic subjects. The vertical dotted lines indicate the Week of the study for which the $\mathrm{Hb} \mathrm{A}_{\mathrm{I}}$ was selected for correlation with the various weekly metabolic parameters. $O=$ Fasting blood glucose; $\bullet=$ Mean capillary glucose; $\square=$ Mean 24 hour urinary glucose; $\Delta=$ Proportion $2 \%$ urine tests; $\boldsymbol{\Delta}=$ Proportion $0 \%$ urine tests

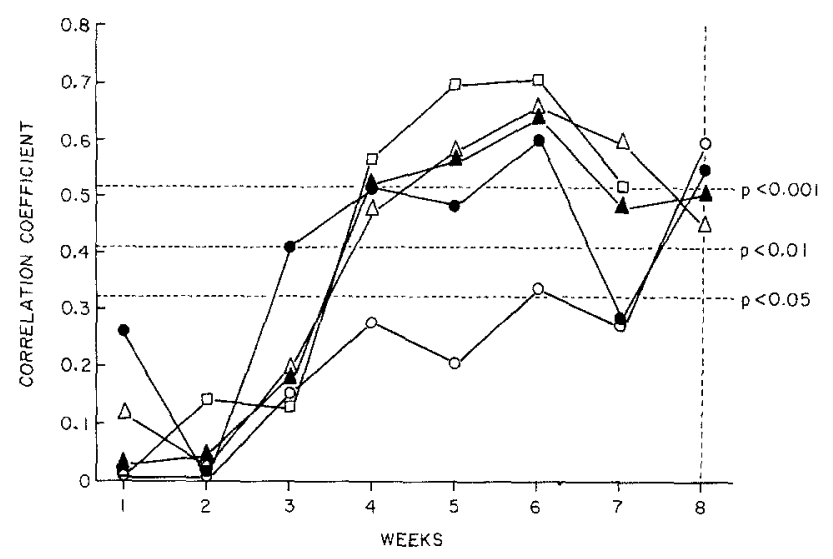

Fig. 4. Correlation coefficients between Week 8 mean 24-hour urinary glucose excretion and the mean weekly metabolic parameters for Weeks $1-8$ for the 38 diabetic patients. The vertical dotted line indicates the Week of study for which the mean 24-hour urinary glucose excretion was selected for correlation with the various weekly metabolic parameters 
Table 3. Correlation coefficients of week eight $\mathrm{Hb} \mathrm{A}_{\mathrm{I}}$ with weekly fasting serum lipid measurements

\begin{tabular}{lllllllll}
\hline Weeks & 1 & 2 & 3 & 4 & 5 & 6 & 7 & 8 \\
\hline Cholesterol mg\% & 0.27 & 0.19 & $0.42^{\mathrm{a}}$ & $0.55^{\mathrm{b}}$ & 0.24 & 0.23 & 0.21 & 0.22 \\
Triglycerides mg\% & 0.14 & 0.35 & $0.46^{\mathrm{b}}$ & $0.41^{\mathrm{a}}$ & 0.33 & 0.13 & $0.47^{\mathrm{b}}$ & 0.20 \\
\hline
\end{tabular}

${ }^{\mathrm{a}} \mathrm{p}<0.05 ;{ }^{\mathrm{b}} \mathrm{p}<0.01$

tic group were consistently greater than the highest values recorded in the nondiabetic subjects. In contrast the diabetic serum cholesterol, serum triglyceride and plasma glucose concentrations overlapped the normal range of values considerably although the mean values were significantly elevated in the diabetic group. These findings are consistent with the generally accepted mechanism of formation of glycosylated haemoglobin in that it is an integral related to the average glucose level to which the haemoglobin is exposed. Consequently, this should provide a better discriminant of diabetic from the nondiabetic than a rapidly fluctuating variable such as the fasting blood sugar. Similarly, the observation that the coefficient of variation of $\mathrm{Hb} \mathrm{A}_{\mathrm{I}}$ for diabetic subjects was only about $50 \%$ greater than that for nondiabetics is in keeping with the notion that $\mathrm{Hb} \mathrm{A}_{\mathrm{I}}$ is a relatively stable parameter.

Somewhat surprisingly, the mean serum growth hormone concentrations did not differ significantly between the diabetic and the nondiabetic groups. Serum growth hormone concentrations have been previously reported to be elevated in juvenile diabetic subjects in basal and ambulant conditions and also in response to provocative stimuli $[23,24,25]$. In the present study, however, it is noteworthy that the growth hormone samples were all drawn under fasting conditions and this restricted sampling may account for the discrepant findings. It has been previously reported that significant differences in diurnal growth hormone concentrations may not be apparent from fasting values alone [26].

To examine the relationship between $\mathrm{Hb} \mathrm{A}_{\mathrm{I}}$ and time averaged blood glucose concentrations, the $\mathrm{Hb}$ $A_{I}$ values from the last week of the study were initially correlated with the average degree of glycaemia present in the antecedent eight weeks of the study. Highly significant correlations were achieved with the various measures of diabetic control, the highest correlations being noted with the mean of the multiple capillary glucose determinations. These findings could be taken to confirm the general premise that $\mathrm{Hb} \mathrm{A}_{\mathrm{I}}$ values provide a reflection of average blood glucose concentrations present for a substantial period of time, in this case, two months. Further analysis, however, of the relative influence of the degree of glycaemia in each week of the study on the subsequent $\mathrm{Hb} \mathrm{A}_{\mathrm{I}}$ values did not confirm this finding.

Thus, it was apparent that the $\mathrm{Hb} \mathrm{A}_{\mathrm{I}}$ values from Week 8 correlated most strongly with the degree of glycaemia present in the four to five weeks prior to the samples. Furthermore, correlation of the $\mathrm{Hb} \mathrm{A}_{\mathrm{I}}$ values from Week 4 of the study confirmed that the highest correlations were those between the $\mathrm{Hb} \mathrm{A}_{\mathrm{I}}$ and the events of the immediately antecedent few weeks. Therefore, it appeared that $\mathrm{Hb} \mathrm{A}_{\mathrm{I}}$ was representative of the average degree of glycaemia present in the four to five weeks prior to the sample and maximally predictive of the degree of glycaemia for the week immediately prior to the sample. Similar correlation analyses of Week 8 mean 24-h urine glucose excretion with these same weekly indices of glycaemia clearly demonstrated that stability of glucose control in the latter half of the study undoubtedly contributed to the high correlations with the Week 8 $\mathrm{Hb} \mathrm{A}_{\mathrm{I}}$ values. Under conditions of acute change in blood glucose control therefore, it is possible that the period of time for which $\mathrm{Hb} \mathrm{A}_{\mathrm{I}}$ is useful as an index of glucose control may be further abbreviated.

These observations are at variance with the view that glycosylated haemoglobin is synthesized slowly and essentially irreversibly over the life span of the red cell, for such a mechanism precludes any abrupt changes in $\mathrm{Hb} \mathrm{A}_{\mathrm{I}}$ concentrations. On the other hand, the published data supporting this concept in the diabetic subject are relatively scant, as mentioned earlier, and also inconclusive. Therefore, while the observations of Gabbay et al. [7] may be taken to indicate that a single $\mathrm{Hb} \mathrm{A}_{\mathrm{I}}$ value is representative of glucose control for a three-month period, it is alternatively possible that the findings of this study were due solely to stability of glucose control in the group studied. The decline in $\mathrm{Hb} \mathrm{A}_{\mathrm{Ic}}$ values noted by Ditzel et al. [11] in a group of diabetics commenced on insulin therapy provides stronger evidence of a relatively rapid decrease in $\mathrm{Hb} \mathrm{A}_{\text {Ic }}$, but unfortunately the associated glucose concentrations that are needed to interpret the rate of decline of the $\mathrm{Hb} \mathrm{A}_{\mathrm{Ic}}$ concentrations are not documented.

The present study and that of Karamanos et al. [15] provide evidence that $\mathrm{Hb} \mathrm{A}_{\mathrm{I}}$, or $\mathrm{Hb} \mathrm{A}_{\mathrm{Tc}}$, may be relatively acutely responsive to changes in blood glu- 
cose concentrations. While the minimum period of time over which a change in blood glucose concentration must be sustained to produce a response in $\mathrm{Hb}$ $A_{I}$ is not clear, it may be of the order of a week or less [15] assuming reasonable accuracy of the method. The mechanism by which these relatively rapid changes in $\mathrm{Hb} \mathrm{A}_{I}$ are produced is not known. Reduced red cell survival in the diabetic is virtually excluded by the study of Peterson et al. [27], for the observed reduction in life span was not adequate to explain the present observations. Dissociation of glycosylated haemoglobin in the stable ketoamine form also seems unlikely [13], but the possibility of a disproportionate increase in the reversible Schiff base moiety in the diabetic has not been excluded. A third theoretical possibility is a disproportionately accelerated synthesis of glycosylated haemoglobin at elevated blood glucose concentrations, but this also is purely conjectural.

Irrespective of the mechanism, it is clear that the kinetic relationship between $\mathrm{Hb} \mathrm{A}_{\mathrm{I}}$ and blood glucose concentrations will need to be carefully defined before glycosylated haemoglobin concentrations can be accurately interpreted as a measure of diabetic control. Nevertheless, it is important to emphasize that an integral of blood glucose concentrations, if only for a period of weeks rather than months, is still clearly superior in simplicity and objectivity to the conventional measures of control. Moreover, the optimum frequency of $\mathrm{Hb} \mathrm{A}_{I}$ determinations required to monitor diabetic control for a protracted period of time will need to be based not solely on kinetic considerations, but also on the actual variability of $\mathrm{Hb} \mathrm{A}_{\mathrm{I}}$ observed in diabetic subjects under daily life conditions. Data on this latter point are currently not available.

There are conflicting reports on the correlation of $\mathrm{Hb} \mathrm{A}_{\mathrm{I}}$ with the fasting concentrations of serum cholesterol and triglycerides [7, 13, 14, 28]. In the present study, the $\mathrm{Hb} \mathrm{A}_{\mathrm{I}}$ values from Week 8 did correlate significantly with the mean serum triglyceride values for Week 3, 4 and 7 and with the serum cholesterol at Weeks 3 and 4 but these correlations were of a low magnitude. A high correlation has been noted by Peterson et al. [28] between $\mathrm{Hb} \mathrm{A}_{\mathrm{Ic}}$ and serum triglycerides, but this study differs from others in that the serum level of triglycerides were considerably elevated prior to institution of rigorous diabetic control. In contrast, in the present study over half the serum triglyceride concentrations of the diabetic subjects were in the normal range and the remainder were not greatly elevated. Therefore, it seems probable that under the more routinely encountered conditions of diabetic control the influence of the degree of glycaemia, as manifested by $\mathrm{Hb} \mathrm{A}_{\mathrm{I}}$ values, on fast- ing cholesterol and triglyceride concentrations is slight.

In summary, this study provides further evidence of the close correlation between $\mathrm{Hb} \mathrm{A}_{\mathrm{I}}$ values and blood glucose concentrations, but additionally it provides evidence that the $\mathrm{Hb} \mathrm{A}_{\mathrm{I}}$ values are relatively more influenced by the degree of glycaemia present in the weeks immediately preceding the test date.

Acknowledgements. We would like to gratefully acknowledge the help and co-operation of the staff and members of the Clara Barton and the E. P. Joslin Diabetic Summer Camps and the technical assistance of Mr. F. McGuire, L. Markowitz, A. Usala and Miss E. Hayes.

This work was presented in part at the 38th Annual Meeting of the American Diabetes Association held in Boston, 1978 (Diabetes 27: 434, 1978). The project was supported by NIH research grants AM-09748, EY-01421, AM-20 530, the Massachusetts Lions Eye Research Fund, Boston, Mass., and the Upjohn Company, Kalamazoo, Michigan. P. J. Dunn was supported by Fogarty International Fellowship 1-F05-TWO-2533-01 and by the New Zealand Diabetes Association. R. A. Cole was supported by NIH training grant AM-07260.

\section{References}

1. Rahbar, S.: An abnormal hemoglobin in the red cells of diabetics. Clin. Chim. Acta 22, 296-298 (1968)

2. Rahbar, S., Blumenfield, O., Ranney, H.M.: Studies of an unusual hemoglobin in patients with diabetes mellitus. Biochem. Biophys. Res. Commun. 36, 838-843 (1969)

3. Bunn, H.F., Haney, D. N., Gabbay, K.H., Gallop, P. M.: Further identification of the nature and linkage of the carbohydrate in hemoglobin $\mathrm{A}_{\mathrm{Ic}}$. Biochem. Biophys. Res. Commun. 67, 103-109 (1975)

4. Bookchin, R. M., Gallop, P. M.: Structure of hemoglobin $A_{\text {Ic }}$. Nature of the $\mathrm{N}$-terminal B-chain blocking group. Biochem. Biophys. Res. Commun. 32, 86-93 (1968)

5. Koenig, R. J., Blobstein, S. H., Cerami, A.: Structure of carbohydrate on hemoglobin $\mathrm{A}_{\mathrm{Ic}}$. J. Biol. Chem. 252, 2992-2997 (1977)

6. Bunn, H. F., Haney, D. M., Kamin, S., Gabbay, K. H., Gallop, P. M.: The biosynthesis of human hemoglobin $\mathrm{A}_{\mathrm{Ic}}$ : Slow glycosylation of hemoglobin in vivo. J. Clin. Invest. 57, 1652-1659 (1976)

7. Gabbay, K. H., Hasty, K., Breslow, J. L., Ellison, R. C., Bunn, H. F., Gallop, P. M.: Glycosylated hemoglobins and long-term blood glucose control in diabetes mellitus. J. Clin. Endocrinol. Metab. 44, 859-864 (1977)

8. Trivelli, L. A., Ranney, H. M., Lai, H.-T.: Hemoglobin components in patients with diabetes mellitus. N. Engl. J. Med. 284, 353-357 (1971)

9. Harris, J. W., Kellermeyer, R. W.: Red cell destruction and the hemolytic disorders (Chapter 9). In: The red cell. Revised ed., pp. 517-523. Cambridge: Harvard Press 1970

10. Peterson, C. M., Jones, R. L.: Minor hemoglobins, diabetic "control" and diseases of postsynthetic protein modification. Ann. Intern. Med. 87, 489-491 (1977)

11. Ditzel, J., Kjaergaard, J.-J.: Hemoglobin $A_{I c}$ concentrations after initial insulin treatment for newly discovered diabetes. Med. J. 1, 741-742 (1978)

12. Koenig, R. J., Peterson, C. M., Jones, R. L., Saudek, C. D., Lehrman, M., Cerami, A.: Correlation of glucose regulation 
and hemoglobin $A_{I c}$ in diabetes mellitus. N. Engl. J. Med. 295, 417-420 (1976)

13. Dolhofer, R., Stadele, A., Wieland, O. H.: Clinical and biochemical studies on the significance and formation of hemoglobin $A_{I C}$ and $A_{I a+b}$ in diabetes mellitus. Klin. Wochenschr. 55, 945-954 (1977)

14. Gonen, B., Rubenstein, A.H., Rochman, H., Tanega, S.P., Horwitz, D. L.: Hemoglobin $A_{1}$ : An indicator of the metabolic control of diabetic patients. Lancet 1977 II, 734-736

15. Karamanos, B., Christacopoulos, P., Zachariou, N., Korkolis, S.: Rapid changes of the hemoglobin $A_{\mathrm{Ic}}\left(\mathrm{Hb} \mathrm{A}_{\mathrm{Ic}}\right)$ fraction following alterations of diabetic control. Diabetologia 13, 406 (1977)

16. Cole, R. A., Soeldner, J. S., Dunn, P. J., Bunn, H. F.: A rapid method for the determination of glycosylated hemoglobins using high pressure liquid chromatography. Metabolism 27, 289-301 (1978)

17. Leon, L., Rush, R. L., Turrell, J.: Automated simultaneous cholesterol and triglyceride determination of the Auto-Analyzer instrument. In: Advances in automated analysis, Vol. 1. Technicon International Congress-1970, pp. 503-507. Miami, Florida: Thurman Assoc. 1971

18. Boden, G., Soeldner, J. S.: A sensitive double antibody radioimmunoassay for human growth hormone (HGH): Levels of $\mathrm{HGH}$ following rapid tolbutamide infusion. Diabetologia 3, 413-421 (1967)

19. Alpert, N. L.: Instrument Series: Report No. 14, Glucose Analyzer and BUN Analyzer. Lab World 24, 40-47 (1973)

20. Sumner, J. B.: A more specific reagent for determinations of sugar in urine. J. Biol. Chem. 65, 393-395 (1925)

21. Armor, D. J., Couch, A.S.: The data text primer. pp. 59-63, 71-74, 92-93. New York: The Free Press 1972
22. Huisman, T. J. H., Dozy, A. M.: Studies on the heterogeneity of hemoglobin. V. Binding of hemoglobin with oxidized glutathione. J. Lab. Clin. Med. 60, 302-319 (1962)

23. Hansen, A.-P.: Abnormal serum growth hormone response to exercise in juvenile diabetics. J. Clin. Invest. 49, 1467-1478 (1970)

24. Hansen, A.-P.: Serum growth hormone patterns in female juvenile diabetics. J. Clin. Endocrinol. Metab. 36, 638-646 (1973)

25. Passa, P., Sauville, C., Canivet, J.: Influence of muscular exercise in plasma levels of growth hormone in diabetics with and without retinopathy. Lancet $\mathbf{1 9 7 4}$ II, 72-74

26. Hanssen, K. F.: Immunoreactive growth hormone in plasma and urine in juvenile diabetics before and during initial insulin treatment. Acta Endocrinol. (Kbh.) 75, 50-63 (1974)

27. Peterson, C.M., Jones, R. L., Koenig, R. J., Melvin, E.T., Lehrman, M. L.: Reversible hematologic sequelae of diabetes mellitus. Ann. Intern. Med. 86, 425-429 (1977)

28. Peterson, C. M., Koenig, R. J., Jones, R. L., Saudek, C. D., Cerami, A.: Correlation of serum triglyceride levels and $\mathrm{Hb}$ $\mathrm{A}_{\mathrm{Ic}}$ concentrations in diabetes mellitus. Diabetes 26, 507-509 (1977)

Received: November 9, 1978, and in revised form: May 22, 1979

Dr. J. S. Soeldner

E. P. Joslin Research Laboratory

Joslin Diabetes Foundation, Inc.

One Joslin Place

Boston, MA 02215

USA 